\title{
A double-voiced reading of Romans 13:1-7 in light of the imperial cult
}

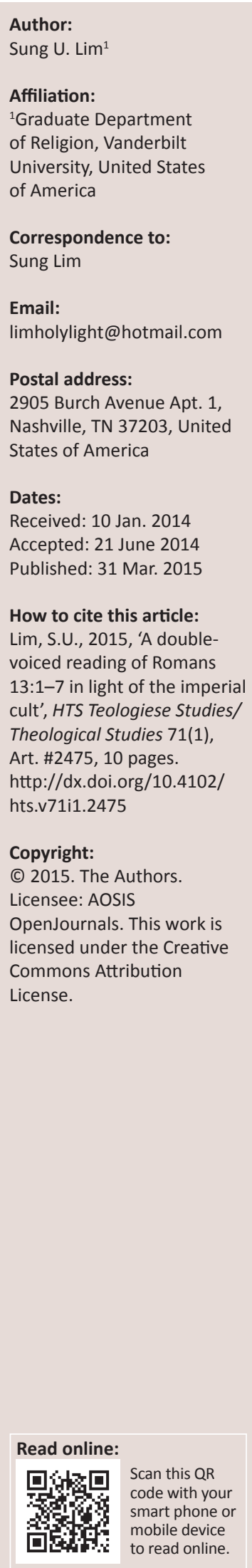

Drawing on Mikhail Bakhtin's theory of double-voicedness and James Scott's theory of public and hidden transcripts, this essay investigates the colonial context of Romans 13:1-7 with particular attention to the Roman imperial cult. It is my contention that Paul attempts to persuade the audience to resist the imperial cult, whilst negotiating colonial power and authority. It is assumed that colonial discourse is, by nature, a double-voiced discourse in that the public transcript of the dominant and the hidden transcript of the suppressed coexist in a continued state of internal tension and conflict. Seen in this light, Paul as a colonised subject parodies the public transcript of the elites in his own hidden transcript. However, Paul's doubled-voiced discourse finally turns out to be subversive against the dominant culture by suggesting that ultimate honour, fear, and authority should not be due to the rulers of the Roman Empire but to God.

\section{Introduction}

This article aims to explore the double-voicedness of Romans 13:1-7 at both the public and hidden levels, paying particular attention to the Roman imperial cult. ${ }^{1}$ The crucial point is that even though Paul affiliates with the colonial authorities at the public level, he persuades the audience to resist them - especially when it comes to the imperial worship - at the hidden level. In other words, Romans 13:1-7 is a double-voiced discourse in the sense that it conveys both the voice of assimilation and the voice of resistance in the colonial milieu. At this point, it should be kept in mind that Paul, a colonised subject, negotiates the Roman Empire. As John W. Marshall (2008:169-170) puts it, Paul affiliates with the colonial authority, whilst at the same time resisting it; ' $[k]$ nowing or choosing when to affiliate and when or how to resist are part and parcel of negotiating life and power in a colonial situation'. In this regard, it would be quite naïve to see Paul either as a completely colonial figure submitting to the imperial power of Rome, or as a completely anti-colonial figure undermining such power. Alternatively, we can portray Paul as both a colonial and anti-colonial figure, since he ceaselessly compromises between submissive and resistant attitudes in such a way as to parodise the rhetoric of the empire. Following this line of reasoning, we can say that Paul rhetorically makes the best of the double-voiced discourse that allows for both compliant and subversive voices simultaneously. Consequently, my contention is that, in Romans 13:1-7, Paul's obedient voice at the public level becomes transformed into his resistant voice at the hidden level to such an extent that it grants the Roman emperors divine honours, which, in an apocalyptic perspective, are diametrically opposite to his anti-idolatry stance (Romans 1:18-32) (cf. Jewett 2006:48-49).

To delve into the ambivalent voice of Romans 13:1-7 within an imperial-colonial context, I will first create an interpretive framework by integrating Mikhail Bakhtin's theory of double-voiced discourse with James Scott's theory of public and hidden transcripts. According to Bakhtin, double-voiced discourse can be defined as a discourse that is deliberately designed to have conflicting references to both the author's speech and the other's speech in an utterance (Bakhtin 1984:184). I will also situate double-voiced discourse within the context of power relations by paying special attention to its public and hidden dimensions. My assumption is that discourse, particularly in a colonial context, tends to be doubly voiced between the public transcript (or, an open discourse between the oppressors and the oppressed) and the hidden transcript (or, a concealed discourse amongst the oppressed) (Scott 1990:1-16).

1.Drawing on my social location related to the context of post-colonial Korean Christianity, this essay sheds new light on the meaning of Romans 13:1-7 with emphasis on the Roman imperial cult. By analogy, the imperial cult under Japanese rule (1910-1945) opens up
new possibilities of examining the given text. All the Koreans under the Japanese occupation were forced to submit to the Japanese new possibilities of examining the given text. All the Koreans under the Japanese occupation were forced to submit to the Japanese
colonial rule. Most, if not all, Korean Christians also had no choice but to politically negotiate with the Japanese reign for their religious colonial rule. Most, if not all, Korean Christians also had no choice but to politically negotiate with the Japanese reign for their religious
faith. It was not until the Japanese colonial empire compelled all Koreans to venerate the Japanese emperor in the Shinto Temple that Korean Christians started to resist it (Herbert 1967:389-425). At that moment, Korean churches were divided into two groups: some Korean Christians started to resist it (Herbert 1967:389-425). At that moment, Korean churches were divided into two groups: some
acquiesced in the Japanese imperial worship, whilst others did not. Regardless of their different positions, the bottom line was that acquiesced in the Japanese imperial worship, whilst others did not. Regardless of their different positions, the bottom line was that
neither of the two groups accepted the divinity of the Japanese emperor. As such, the ferocity of the Japanese colonial rule alerts this author to the historical possibility that Romans 13:1-7 has much to do with the issue of the imperial cult in particular as well as the issue of submission to the governing authorities in general. 
Secondly, I will proceed to bring to the fore the Roman imperial cult and, by contrast, Paul's anti-idolatry stance in a critical engagement with the public transcript of the elites and the hidden transcript of the subordinates. Greek and Roman sources extensively demonstrate that the elites in the Roman Empire sanction the imperial cult as an ideological enterprise in the public transcript. On the other hand, Paul, a colonised subject, hints at his considerable opposition to emperor worship in the hidden transcript by delivering his blistering polemic against idolatry in Romans 1:18-32 from an apocalyptic perspective.

Thirdly, I will look more closely at Romans 13:1-7 against this background. Considering that Paul mediates between the ideology of the elites and the ideology of the subordinates, I will show that Romans $13: 1-7$, as a colonial discourse, turns out to be double-voiced by conveying both the voice of submission in the public transcript and the voice of resistance in the hidden transcript. Especially, the double-voicedness of honour, fear and authority reveals that Paul implicitly triggers resistance against the public transcript of the elites in his hidden transcript.

\section{A double-voiced reading within the framework of public or hidden transcripts}

In order to establish an interpretive framework for Romans 13:1-7, I will blend Bakhtin's double-voiced discourse with Scott's public or hidden transcripts. In the first place, Bakhtin's notion of double-voiced discourse provides a clue to rereading Romans 13:1-7 in a fresh way. Before elaborating on Bakhtin's notion of double-voiced discourse, it is of great use to make a distinction between monologue and dialogue and, furthermore, between monologism and dialogism for a deeper understanding of double-voicedness (cf. Holoquist 2002).

For Bakhtin, monologue is a unitary speech where one voice alone is predominant, whilst dialogue is a manifold speech where a multiplicity of voices co-exists. To take a step further, monologism, on the one hand, is a finalised consciousness repudiating the existence of another consciousness beyond itself (Bakhtin 1984:292-293). On the other hand, dialogism is an unfinalisable consciousness in on-going interactions with the other consciousnesses (Bakhtin 1984:293).

Interestingly, Bakhtin (1984:184) points out that dialogism is coupled with double-voicedness in that dialogic speech can find traces of clashing voices in a discourse: 'Thus dialogic relationships can permeate inside the utterance, even inside the individual word, as long as two voices collide within it dialogically'. For the most part, double-voiced discourse indicates the dynamic relationship between two different voices consisting of both what the author intends and what the other intends.
More specifically, Bakhtin divides double-discourse into three categories: unidirectional double-voiced discourse; varidirectional double-voiced discourse; active double-voiced discourse. The first category (unidirectional double-voiced discourse) refers to the double-voiced discourse in which the author's discourse agrees with the other's discourse. The second category (vari-directional double-voiced discourse) is a discourse wherein the other's discourse is introduced to serve the directly opposing intention of the author's discourse and is frequently seen in parody and irony (Bakhtin 1984:193). The third category (active double-voiced discourse) makes use of the other's discourse for the sake of the author's discourse without any direct reference (Bakhtin 1984:195-196). As can be seen below, it is apparent that varidirectional double-voiced discourse is more germane to the interpretation of the pericope than any other category, since Paul ostensibly adopts the dominant discourse of the Roman Empire, but eventually espouses its opposing discourse, that is, anti-dominant discourse. Let us consider for a moment what Bakhtin (1984) articulates vari-directional double-voiced discourse:

In vari-directional discourse, on the other hand, a decrease in objectification and a corresponding heightening of activity on the part of the aspirations of the other discourse lead inevitably to an internal dialogization of discourse. In such discourse, the author's thought no longer oppressively dominates the other's thought, discourse loses its composure and confidence, becomes agitated, internally undecided and two-faced. Such discourse is not only double-voiced but also double-accented; it is difficult to speak it out aloud, for loud and living intonation excessively monologizes discourse and cannot do justice to the other person's voice in it. (p. 198)

It is interesting to note that, in vari-directional double-voiced discourse, the author's discourse is not more dominant than the other's discourse; conversely, the other's discourse is not more dominant than the author's discourse, either. That is to say, the author's discourse and the other's discourse are so equally internalised that it becomes an ambivalent discourse. Such ambivalence creates a perfect space for the coexistence of jarring voices. In my opinion, the concept of vari-directional double-voiced discourse thus leads to a deeper understanding of the ambivalence of colonial discourse replete with both dominant and marginal voices. Nevertheless, this concept also demonstrates a lack of understanding of the power differences that underlie double-voiced discourse.

In the second place, Scott's public or hidden transcripts can supplement Bakhtin's double-voiced discourse in an imperial-colonial context (Lim 2011:127). As can be seen below, I will contend that the public transcript of the dominant and the hidden transcript of the suppressed are so internally dialogised in a colonial discourse that they become easily double-voiced in it.

By definition, the public transcript is 'a shorthand way of describing the open interaction between subordinates and those who dominate' (Scott 1990:2). Put crudely, Scott sees the public transcript as 'the self-portrait of dominant elites as they 
would have themselves seen' (Scott 1990:18). On the contrary, the hidden transcript, for Scott (1990:4), is characterised as 'the discourse that takes place "offstage", beyond direct observation by power-holders'. What is interesting is that the public transcript of the dominant functions as the sociological, cultural ideology of the dominant society. This implies that the subordinates mainly depend for their survival upon their affiliation with the onstage script of the elites. Moreover, the hidden transcript of the subordinates operates 'offstage,' away from the purview of the power-holders. The oppressed outwardly affirm their affiliation with the elites, whilst hiding their resistance behind their backs. Nevertheless, the hidden transcript of the weak, as M.A. Stubbs (2004:184) argues, is not in the least 'weak' because it is not just restricted to offstage. Rather, it may serve as a 'politics of disguise and anonymity that takes place in public view but is designed to have a double meaning or to shield the identity of the actors (Scott 1990:19)'. This suggests that the subordinates transform the hidden transcript offstage into the public transcript onstage in a mask:

the greater the disparity in power between dominant and subordinate and the more arbitrarily it is exercised, the more the public transcript of subordinates will take on a stereotyped, ritualistic cast. In other words, the more menacing the power, the thicker the mask. (Scott 1990:3)

From this it follows that the public transcript of the subordinates is usually double-voiced, whilst simultaneously stressing the voice of affiliation and hiding the voice of resistance. $^{2}$

Thus, to masquerade the hidden transcript of the subordinates as the public transcript of the elites is a strategy for resisting imperial or colonial discourse by means of conformity. The result is that the subordinates mimic the elites (cf. Bhabha 1994:85-92). As such, colonial mimicry may 'appear to parody whatever it mimics' (Ashcroft, Griffiths \& Tiffin 2000:114). The hidden transcript of the subordinates should be a mimicry, or even parody, of the public transcript of the elites in order that the first may be disguised as the second with the view to avoiding the surveillance of those in power. Following in the footsteps of both Bakhtin and Scott, I assert that it is through parody that the hidden voice of the subordinates co-exists and clashes with the public voice of the elites in a way that the first at once resembles and menaces the second.

In summary, I have thus far developed an interpretive framework for Romans 13:1-7: a double-voiced reading within the framework of public or hidden transcripts. This framework will enable us to scrutinise the double-voicedness of the given text in the imperial-colonial milieu. I will decode the double-voicedness of Romans 13:1-7 with special reference to the imperial cult, using the concepts of the public and hidden transcripts.

2.The double-voicedness of the imperial-colonial discourse of the subordinates 21-22) notes: 'Such a double life with double thoughts, double duties, and double social classes, must give rise to double words and double ideals, and tempt the mind to pretense or revolt, to hypocrisy or radicalism'.

\section{The imperial cult in the public transcript and the hidden transcript The imperial cult in the Roman elite's public
transcript}

The primary task of this section is to juxtapose the public transcript of the elites - as widely attested in Greco-Roman literature - with the hidden transcript of the subordinates as presented by Paul as a colonised subject - with regard to the Roman imperial cult. Firstly, I will demonstrate that the elites endorse the imperial cult in the public transcript, manifesting its ruling power to the subjects of the empire (Price 1998:1). Secondly, I will show that Paul disguises his resistance against emperor worship as his anti-idolatry stance (Romans 1:18-32) in the hidden transcript.

On the one hand, the public transcript of the elites corroborates their vigorous espousal of the worship of Roman emperors. As the Roman Empire spread its power throughout the whole Mediterranean basin, it begun to develop the imperial cult as a key propaganda of public ideology under the great influence of the Hellenistic ruler cult (Fears 1988:1014; cf. Price 1998). Above all, Caesar received a variety of honours, both human and divine, in his lifetime. For instance, Cassius Dio (155-235 C.E.) reports that Caesar accepted 'the novel and excessive honours' ( $\tau \alpha$ ĩ $\tau \varepsilon$

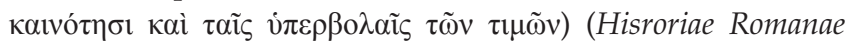
44.3.1) and received such honourific titles as 'demigod'

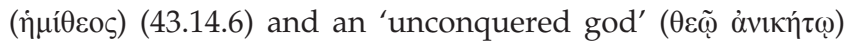
(43.45.3) from the Roman Senate. ${ }^{3}$ Seutonius (c. 69 - after 122 C.E.) (Julius 76.1) also recounts that Caesar received 'excessive honours' (honores modo snimios) even for a mortal man. In similar fashion, Appian (c. 95-165 C.E. - Bella Civilia 2.106) also describes that 'all kinds of honours were immensely devised for his gratification, even such as were beyond humanity-concerning sacrifices, games, statues in all the temples and public places, by each tribe, amongst all nations,

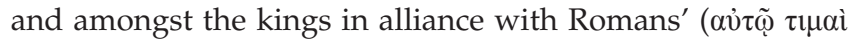

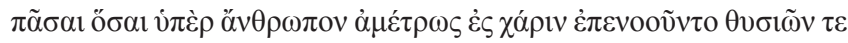

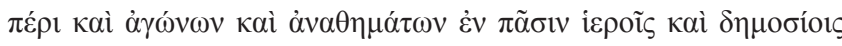

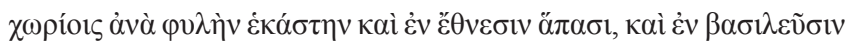

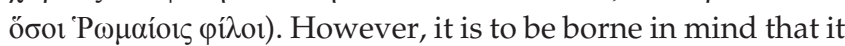
is after his death that Caesar received the honours as a state divinity (cf. Cicero Philippics 2.110). ${ }^{4}$ In this connection, Appian explicates the posthumous divinisation of Caesar by the Roman state:

There an altar was first erected, but now there stands the temple of Caesar himself, as he was deemed worthy of divine honours ( $\theta \varepsilon i ́ \omega v \tau \imath \mu \tilde{\omega})$; for Octavian, his son by adoption, who took the name of Caesar, and, following in his footsteps in political matters, greatly strengthened the government which was founded by Caesar, and remains to this day, decreed godlike honours ( $\tau \mu \tilde{\omega} v$ i $\sigma 0 \theta \varepsilon \dot{\varepsilon} \omega v)$ to his father. From this example the

3.All translations of original texts, Greek and Latin, are mine, unless otherwise specified.

4.Cicero in his second Philippics derided Mark Antony as he ignored Caesar's honours Cicero in his second Philippics derided Mark Antony as he ignored Caesar's honours
of state divinity. Antony was afraid that an attempt to deify Caesar would be of state divinity. Antony was afraid that an attempt to deify Caesar would be
beneficial to his rival, young Octavian, as Caesar's adopted son and heir (cf. Gradel 2002:56-57). 
Romans now pay like honours to each emperor at his death if he has not reigned in a tyrannical manner or made himself odious, although at first they could not bear to call them kings even while alive. (Bella Civilia 2.148)

As Appian put it, it was common that the Roman state posthumously bestowed the title Divus upon its emperors because they rejected their deification in their lifetime (Gradel 2002:261).

Augustus was also praised and honoured by Roman popularity as a restorer of peace, security and prosperity to the Roman world. One of the best pieces of evidence is an inscription from Priene (9 B.C.E.) concerned with the installation of the new year to the birthday of Augustus (September 23). Part of the inscription is in what follows:

Whereas the Providence [Pronoia] which has regulated our whole existence, and which has shown such care and liberality, has brought our life to the climax of perfection in giving to us [the emperor] Augustus, whom it [Providence] filled with virtue for the welfare of men, and who, being sent to us and our descendants as a Saviour [Soter], has put an end to war and has set all things in order; and [whereas,] having become manifest [phanesis], Caesar has fulfilled all the hopes of earlier times ... not only in surpassing all the benefactors [euergetai] who preceded him but also in leaving to his successors no hope of surpassing him; and whereas, finally, the birthday of the god [Augustus] has been for the whole world the beginning of good news [euangelion] concerning him [therefore, let a new era begin from his birth, and let his birthday mark the beginning of the new year] (Grant 1957:174; emphasis mine)

More striking is the following inscription at Myra in Lycia found under a statue of Augustus:

The god Augustus, Son of God, Caesar, Autocrat [Autokrator, i.e., absolute ruler] of land and sea, the Benefactor and Saviour of the whole cosmos, the people of Myra [acknowledgement, or, have set up this statue] (Grant 1957:175; emphasis mine)

Strikingly enough, the imperial cult reflects the rhetoric of empire, which praises the Roman emperor as a benefactor, saviour and son of God to deliver good news to the world. In the same way, Virgil (70-19 B.C.E.), one of the greatest imperial poets, eulogises the Roman Empire and emperor in Aeneid and Fourth Eclogues. In celebration of Octavian's inauguration of the first Roman emperor in the year 27 B.C.E., Virgil envisages the golden age: His ego nec metas rerum nec tempora pono; Imperium sine fine dedi [For these I set no bounds in space or time; but have given empire without end] (Virgil Aeneid 1.278-279). Virgil also sought to propagandise Roman imperialism by praising peace and security through victory: ('you, Roman, be sure to rule the world (be these your arts), to crown peace with justice, to spare the vanquished and to crush the proud' ( $t u$ regere imperio populus, Romane, memento (hae tibi erunt artes), pacique imponere morem, parcere subiectis et debellare superbos) (Aeneid 6.851-853).

In addition to glorifying the Roman Empire, Virgil attempts to honour and further deify the Roman emperor. Above all, in the Fourth Eclogues, which was written in celebration of the birth of a child in 40 B.C.E., the year of the marriage of Antony and Octavia, he depicts the world as worshipping the child, which adumbrates Roman ruler cult:

'O enter upon your high honours-the hour will soon be here dear offspring of the gods, mighty seed of a Jupiter to be! See how the world bows with its massive dome-earth and expanse of sea and heaven's depth! See how all things rejoice in the age that is at hand!' [Adgredere o magnos - aderit iam tempus-honores, cara deum suboles, magnum Iovis incrementum! Aspice convexo nutantem pondere mundum, terrasque tractusque maris caelumque profundum! Aspice, venturo laetentur ut omnia saeclo!] (Canick 1998:118; Eclogues 4.48-52)

Assured that, in the Augustan age, peace and security dominate the world with eternity, Virgil goes so far as to proclaim that Augustus is the son of a god, who will establish the golden age:

And this in truth is he whom you so often hear promised you, Augustus Caesar, son of a god [divi genus], who will again establish a golden age in Latium amid fields once ruled by Saturn. (Aeneid 6.791-794)

Thus, Virgil attempts to deify Augustus as son of a god.

In a similar vein, Horace (65-8 B.C.E.) (Epistles 2.1.15-16) also declares the divinity (numen) of the living emperor Augustus, giving him fullest honour (muturos honores):

Praesenti tibi maturos largimur honores iurandasque tuom per numen ponimus aras

We bestow the fullest honours on you who are present, and we set up altars on which to swear by your divinity.

Horace attests to the divine power of Caesar in his lifetime (Koortbojian 2013:158-9, 172).

As Tacitus (Annals 1.10.7) put it, it is remarkable that Augustus himself made explicit his desire for post mortem deification, a craving to be worshipped with divine honours in his lifetime: 'No honour was left for the gods, when Augustus chose to be himself worshipped with temples and statues, like those of the deities, and with flamens and priests' (nihil deorum honoribus relictum cum se templis et effigie numinum per flamines et sacerdotes coli vellet). In spite of Augustus's desire, it is after his death that the Roman state started to consecrate him with divine honours. Cassius Dio (Hisroriae Romanae 56.46.1-4) goes to great length to describe the posthumous deification of Augustus as a Roman state deity. ${ }^{5}$

What is interesting is that such Roman emperors as Gaius and Nero keenly demanded their worship even in their

\footnotetext{
5. Now these rumours began to be current at a later date. At the time they declared Augustus immortal, assigned to him priests and sacred rites, and made Livia, who was already called Julia, and Augusta, his priestess; they also permitted her to employ a lictor when she exercised her sacred office. On her part, she bestowed a million sesterces upon a certain Numerius Atticus, a senator and ex-praetor, because he swore that he had seen Augustus ascending to heaven after the manner because he swore that he had seen Augustus ascending to heaven after the manne of which tradition tells concerning Proculus and Romulus. A shrine voted by the senate and built by Livia and Tiberius was erected to the dead emperor in Rome, and others in many different places, some of the communities voluntarily building them and others unwillingly. Also the house at Nola where he passed away was dedicated to him as a precinct. Whilst his shrine was being erected in Rome, they placed a golden image of him on a couch in the temple of Mars, and to this they paid all the honours that they were afterwards to give to his statue.'
} 
lifetime. Gaius (12-41 C.E.), whose nickname was Caligula, claimed that his subjects should pay him divine honours. In the words of Philo Judaeus (c. 20 B.C.E-c. 50 C.E.), 'Gaius puffed himself up with pride, not only saying, but even

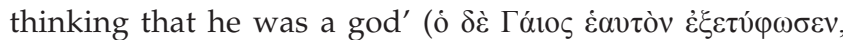

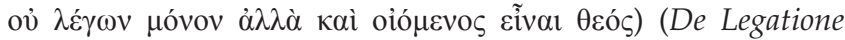
ad Gaium 162). For instance, Gaius erected the temple at Miletus in the province of Asia and two temples of his own in Rome (Cassius Dio Historiae Romanae 59.28.1-4). In particular, the deification of Gaius was a stumbling block for the contemporary Jews in the eastern Mediterranean (McLaren 2005). When there took place a clash in Alexandria between the Jews and the Greeks around 38 C.E., the Greeks demolished the synagogues of the Jews, setting up the images and statues of Gaius inside them (Philo De Lgatione ad Gaium 134). As a punishment for the Jews' destruction of the altar erected by the Greeks at Jamnia in favour of

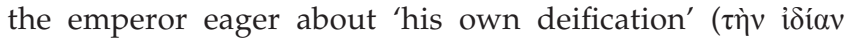
$\dot{\varepsilon} \kappa \theta \dot{\varepsilon} \omega \sigma \iota v)$, Gaius also commanded Petronius, the governor of Syria, to erect a colossal statue of himself in the temple of Jerusalem in 39 C.E. (Philo De Legatione ad Gaium 200-203; cf. Bilde 1978).

Similarly, Nero had a colossal statue of himself, which is more than one hundred feet in height, made by Xenodotus, a Greek artist, (Pliny the Elder Naturalis Historia 34.18; Seutonius Nero 31). What is striking is that during 59 C.E. Nero set up an idiosyncratic corps of about five thousand

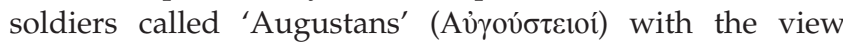
of leading the acclamations ( $\dot{\varepsilon} \pi \alpha i v \omega v)$ when he made an appearance in the theatre by exclaiming: 'Our Glorious Caesar, our Apollo, our Augustus, like another Pythian! By thyself we swear, O Caesar, none surpasses thee' (ó $\kappa a \lambda$ ò $\varsigma$

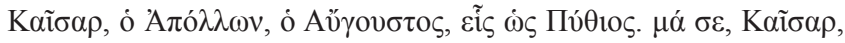

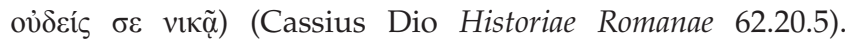
As Jones (1980:1030) puts it, such acclaims convey divine overtones as they relate to emperor worship. In 66 C.E., Nero took pleasure in his deification, especially when Tiridates, a Parthian prince, expressed the willingness to worship him as a god by speaking thus: 'And I have come to thee, my god,

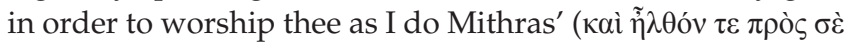

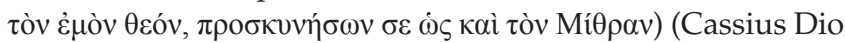
Historiae Romanae 63.5.2).

By contrast, it should also be remembered that not all the Roman emperors were enthusiastic about divine honours granted to them. To illustrate, Tiberius (42 B.C.E.-37 C.E.) and Claudius (10-54 C.E.) considered the divine claims of Roman emperors as ridiculous, therefore refusing to receive any honours, particularly in their lifetime. For instance, when the province of Further Spain made a request to erect a temple to Tiberius and his mother, he expressed his strong contempt for divine claims by saying: 'As myself, Conscript Fathers [i.e. Senators], that I am mortal, that I am engaged in the functions of men' [Ego me, patres conscripti, mortalem esse et hominum officia fungi] (Tacitus Annals 4.38). Like Tiberius, Claudius typically, but not always, refused divine honours. Even when he occasionally consented to the erection of the statues of himself and his family,
Claudius in his letter to the Alexandrians restricted divine honours to deity alone:

But I deprecate the appointment of a high priest to me and the building of temples, for I do not wish to be offensive to my contemporaries, and my opinion is that temples and such forms of honour have by all ages been granted as a prerogative to the gods alone. (Hunt \& Edgar 1934:78-79)

But paradoxically, in spite of all the efforts of Tiberius and Claudius to resist divine honours, it cannot be denied that the imperial cult was an immensely popular cultural phenomenon that pervaded the 1st century Mediterranean basin and beyond.

\section{The imperial cult in Paul's hidden transcript}

On the other hand, Paul in his letter to the Romans - as a hidden transcript - hints at his indictment for the imperial cult as he deals with the issue of idolatry in Romans 1:18-32. Prior to analysing his thinly disguised critique of the imperial cult as a form of idolatry, it is prerequisite to clarify what is meant by idolatry. According to Daniel Patte (1983:266, 273-274), idolatry has much to do with a human desire to absolutise an image ( specifically, humanity has a sinful tendency to replace God with a fixed image of a creature, say, a mortal human being or animal. Simply, idolatry can be defined as the worship of creation and created things in place of God.

Keeping this in mind, I will briefly examine the ways in which Paul discusses idolatry in Romans 1:18-32. Paul first affirms that God's wrath pertains to all ungodliness ( $\alpha \sigma \varepsilon \dot{\varepsilon} \beta \varepsilon \alpha)$ and injustice ( $\dot{\alpha} \delta 1 \kappa i ́ \alpha)$ of men (Romans 1:18). Paul goes on to say that such ungodliness and injustice culminates in the worship of created things on the grounds that they do not reveal God any longer (Romans 1:19-23). Then Paul connects idolatrous behaviours to a lust or degrading passion grounded in sexual relations (Romans 1:24-27). Finally, Paul concludes by asserting that deserting God results in a variety of forms of vices in practice (Romans 1:28-32).

Clearly, Romans 1:18-32 touches on Paul's vehement position against idolatry at first glance. From his general accusations of idolatry it follows that Paul is particularly aware of the idolatrous nature of the imperial cult as well. The reason is that the imperial cult exchanges the honour ( $\delta$ ó $\xi \alpha)$ of the immortal God with the honour of emperor, a mortal human being, thereby worshipping ( $\left.\sigma \varepsilon \beta \alpha \dot{\zeta} \zeta{ }_{0} \mu \alpha\right)$ and serving $(\lambda \alpha \tau \rho \varepsilon v ́ \omega)$ the creature rather than the creator (cf. Romans 1:21, 23, 25).

To begin with, the Greek terms concerned with the honour of God, for instance, $\delta$ o $\xi \alpha \dot{\zeta} \varepsilon v$ [to honour] and $\delta$ ó $\xi \alpha$ [honour] echo the honour terms granted to the Roman emperors (Romans 1:21, 23). As we have seen above, it was commonly held that, in the Greco-Roman culture, divine honours were deemed to fit in well with the status of Roman emperors. According to J.E. Lendon (1997:272-279), such Greek words

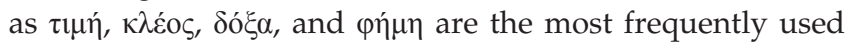
ones to express the divine honours awarded to Roman 
emperors. Paul, however, claims that the honour due to the immortal (״丷 $\varphi \theta \alpha \rho \tau \varsigma \varsigma)$ God is by no means interchangeable with the honour due to a mortal [ $\varphi \theta \alpha \rho \tau$ cos] human being, not to mention a Roman emperor (Romans 1:23). This suggests that Paul disapproves of the worship of emperors as Rome's official deities.

Next, Paul's use of the Greek verbs $\sigma \varepsilon \beta \alpha \dot{\alpha} \zeta \varepsilon \sigma \theta \alpha 1$ [to worship' or 'to show honour to] and $\lambda \alpha \tau \rho \varepsilon v i \varepsilon v$ [to worship with cultic honouring] also gives a clue to his attention to the worship of Roman emperors (Romans 1:25). As Robert Jewett (2006: 170-171) aptly argues, $\sigma \varepsilon \beta \alpha ́ \zeta \varepsilon \sigma \theta \alpha 1$ appears only once in the New Testament, which is also closely associated with Roman religion, and perhaps more particularly, emperor worship. Jewett (2006:170) also notes that $\sigma \varepsilon \beta \alpha \sigma \tau o ́$, a verbal adjective form of $\sigma \varepsilon \beta \alpha \dot{\alpha} \zeta \varepsilon \sigma \theta \alpha 1$, is exactly equivalent to the Latin term Augustus, an ancient Roman title given initially to Octavian and subsequently to his successors. Remarkably, Philo states:

And yet if new and unprecedented honours ( $\left.\tau \mu \alpha \alpha_{\varsigma}\right)$ should have been voted to anyone, it was fitting to him, not only because he was the origin and fountain of the Augustan ( $\sigma \varepsilon \beta \alpha \sigma \tau$ oṽ) dynasty, nor because he was the first, and greatest, and universal benefactor, having, instead of the rule of many who existed before, entrusted the common vessel of the state to himself as a pilot of admirable grasp of the science of government to steer for the verse, 'the rule of many is not good' is very properly expressed, since a multitude of votes is the cause of a variety of evils - but also because even the whole world voted him honours ( $\tau \mu \grave{\alpha} \varsigma)$ equal to those of the Olympians. (De Legatione ad Gaium 149; emphasis mine)

Philo delivers a eulogy for Augustus awarded divine honours equivalent to those of the Olympians, allegedly Olympian deities. According to Philo, it is common that the title $\sigma \varepsilon \beta \alpha \sigma \tau$ ó $\varsigma$ in the Mediterranean world of the 1st century was intimately connected to the divine honours ( $\tau \mu \tilde{\alpha} \imath)$ of Roman emperors in the context of the imperial cult (on the

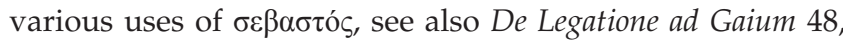
143-144, 151, 291, 305, 309, 311, 317, 319, 321, 352).

Finally, the Greek verb $\lambda \alpha \tau \rho \varepsilon v i \varepsilon v$ calls attention to cultic worship. As H. Strathmann (1983:60-61) argues, $\lambda \alpha \tau \rho \varepsilon v i \varepsilon ı v$ in the LXX refers either to the cultic worship of Israel's God (e.g. Exodus 23:25; Deuteronomy 6:13; Joshua 22:27; 2 Samuel 15:8) or to that of idols (e.g. Exodus 20:5; Leviticus 18:21; Deuteronomy 4:28; Joshua 24:14; Judges 2:19), not to mention that of the ruler, that is, Nebuchadnezzar II (634-562 B.C.E.) (Daniel 3:18). Against this background the meaning of $\lambda \alpha \tau \rho \varepsilon v i \varepsilon v$ leans toward the cultic worship of the creation rather than the creator (cf. Acts 7:42). Here, it is noteworthy to remember that the imperial cult was one of the most widely known popular cults in Paul's time. Accordingly, Paul is highly likely to be alert to the practice of the imperial cult widespread in the Mediterranean basin.

Thus, Paul, implicitly rather than explicitly, finds fault with the imperial cult as a form of idolatry. Apparently, the Roman elite's public transcript has demonstrated that the worship of the emperors was common and predominant in the 1st century Mediterranean world. However, Paul's harsh polemic against polytheistic idolatry in Romans 1: 18-32 provides ample reason to suppose that he denounces emperor worship as a type of idolatry. The reason is that Paul fundamentally takes on apocalyptic theology that God provisionally 'hands over' ( $\pi \alpha \rho \alpha \delta i \delta \omega \mu$; Romans 1:24, 26, 28) humanity to the evil powers that will be put to an end by the other type of handing over that is pinnacled upon the resurrection of Jesus Christ (Romans 8:32) (Gaventa 2005: 42-53). Remarkably, Paul in his hidden transcript conceals his charges with emperor worship in an apocalyptic perspective.

It is important to draw attention to the political as well as religious characteristics of the imperial cult in order to explain the circumstances that drive Paul to make use of hidden transcript. The worship of emperor was both a religious and political phenomenon since it promoted the political propaganda of the Roman Empire through a religious apparatus. To put it otherwise, such imperial religion as emperor worship was indissolubly connected with imperial politics, given the fact that there was not a clearcut distinction between religion and politics in the ancient world. The imperial cult served to make Roman subjects loyal to their emperor and state by worshipping them as deities (Fears 1988:1018; Wengst 1997:50). As R. Horsley (1997:1-8) argues, Paul is sufficiently sensitive to the 'Roman imperial religio-politics' as presented by the imperial cult. For this reason, Paul as a colonised subject has no choice but to disguise his particular denunciation of emperor worship as a general polemic against idolatry. Otherwise, his forthright accusation on the worship of emperors would be construed as a radical challenge to their governing authority. As a consequence, Paul inscribes his subversive message against the public discourse of the imperial cult in his hidden transcript to eschew the surveillance of the power-holders.

\section{A double-voiced reading of Romans 13:1-7 A public voice of Romans 13:1-7}

Thus far, we have investigated the public transcript of the elites and the hidden transcript of a subordinate, Paul, with focus on the Roman imperial cult. As can be seen above, the subordinates mimic the elites so that the former's hidden transcript may be disguised as the latter's public transcript. As such, the masquerade of hidden transcript as public transcript brings about a space for a double-voiced discourse. As a consequence, public and hidden voices co-exist and clash with each other (Wan 2008:173-184). I will demonstrate that Paul's discourse in Romans 13:1-7 - as a hidden transcript masquerading as a public transcript - is double-voiced between the public voice of the elites and the hidden voice of the subordinates, especially when read in the light of the imperial cult.

On the one hand, I will attempt to pinpoint the public voice of Romans 13:1-7, supposing that the passage would have been read or heard by the elites (Wan 2008:174-176). First, 
the Roman elites would understand the passage to justify their authority as rulers in the political system. This passage appeases, at first glance, the elites of the Roman Empire by proclaiming: 'let every soul submit itself to governing

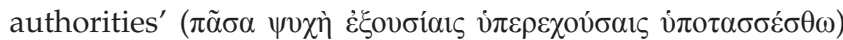
(Romans 13:1). The Greek term $\dot{\varepsilon} \xi o v \sigma i ́ \alpha$ has a broad range of meanings, e.g. 'freedom', 'ability', and 'authority'. As Joseph A. Fitzmyer (1993:666) suggests, Paul's vocabulary - for

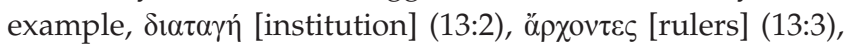

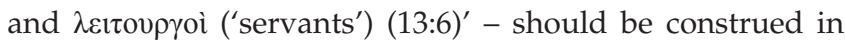
the context of the Roman political administration. That being the case, $\dot{\varepsilon} \xi o v \sigma i \alpha$ is also taken to mean authority more than anything else. Fitzmyer (1993:666) also argues that $\dot{\varepsilon} \xi o v \sigma i ́ \alpha$ in the plural form commonly denotes human authorities.

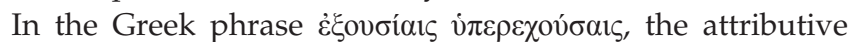

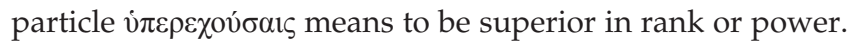

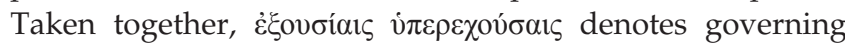
authorities, referring particularly to local officials in the concrete rather than the state in the abstract (Wan 2008:175). Furthermore, the statement that 'whoever resists authority

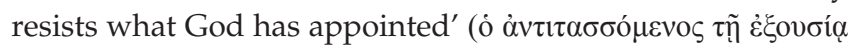

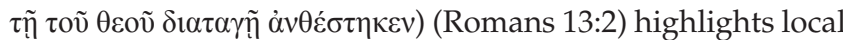
officials' authority, which is instituted by God (Romans 13:1). Thus, the passage seems to espouse submission to Roman local officials and their authority.

Second, the ruling elites of Rome would also find the passage to support their exercise of power over the ruled. As noted earlier, of ö $p \chi 0 v \tau \varepsilon \varsigma$ (Romans 13:3) in the Greco-Roman political administration means 'the public officials' (Jewett 2006:792). In such a political context, the officials do not become fearful objects to those performing 'good conduct' ( $\alpha \gamma \alpha \theta \tilde{\omega}$ है $\rho \gamma \omega)$, but

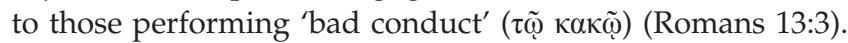
Put otherwise, 'the good' ( $\tau$ ò $\alpha \gamma \alpha \theta$ óv) brings about 'praise'

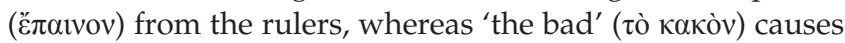

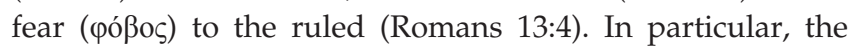
sword ( $\mu \alpha \alpha \alpha \iota \rho \alpha)$ born by 'God's servant' ( $\theta \varepsilon \circ v \tilde{~ \delta i \alpha ́ \kappa o v o ́ \varsigma) ~-~ a ~}$ referent to the Roman officials in context - makes legitimate the ferocity of violence done by the military power. As 'God's

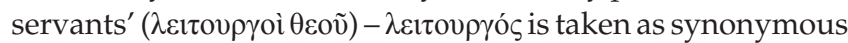

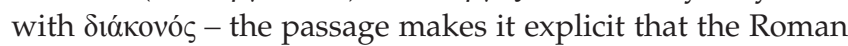
officials are specifically responsible for collecting taxes as part of the economic system of the Roman Empire (Romans 13:6-7). It is assumed that paying taxes - composed of pópos [tribute tax] and $\tau \dot{\lambda} \lambda o \varsigma$ [custom tax] (cf. Tacitus Annals 13:5051 ) - is a good conduct deserving praise, whereas not paying taxes is a bad conduct entailing fear of violence (McDonald 1989). What is more, the exhortation to pay 'fear to whom fear

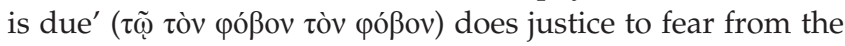
Roman magistrates. In the long run, the passage seems to justify the fearful power of the Roman ruling elites.

Last, but most important, the Roman elites would find themselves to deserve the honour due to them. Truly, honour in the Greco-Roman world is attributable to the ruling elites, whether they are officials or emperors. Given the prevalence of the imperial cult in the Mediterranean world, the

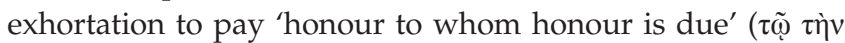

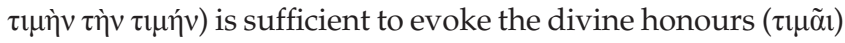

granted exceptionally to Roman emperors. (Jewett 2006:803). As we have already seen (3.1.), the public transcript of the elites shows that the Roman Empire compelled its subjects to venerate the emperors as deities in order to make them loyal to the imperial order. To recapitulate, Caesar was awarded

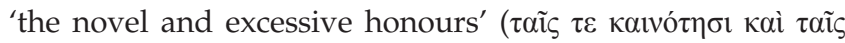

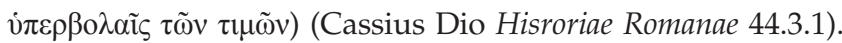
In the process of posthumous divinisation, Caesar was also

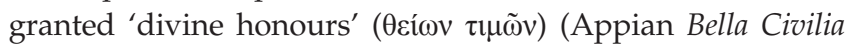
2.148). Likewise, Octavian was accorded highest honour (honour) as a son of god (divi genus) (Virgil Eclogues 4.48-52). He was even deemed to have the 'divine nature' (numen) as a sign of fullest honour (muturos honores) (Horace Epistles 2.1.15-16). Interestingly, Gaius was keenly enthusiastic about 'his own deification' ( ad Gaium 201). In similar fashion, Nero also demanded his

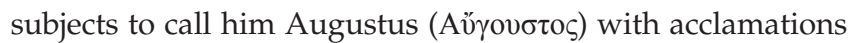

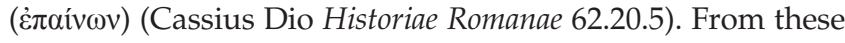
observations it follows that prominent honour ( $\tau 1 \mu \eta$ ) was held to be ascribable to emperors more than anyone else in the Roman Empire. Therefore, the passage would be regarded as endorsing the divine honours of Roman emperors in the context of the imperial cult. Hence, as S. Wan (2008:176) puts it, the Roman elites would understand the passage to champion the power and legitimacy of the Roman Empire. But at the same time, it should be remembered that the passage is written with a double voice, both public and hidden.

\section{A hidden voice of Romans 13:1-7}

On the other hand, I will deliberately uncover the hidden voice of the passage in the opposite order to its public voice. As Wan (2008:177) cogently claims, the same passage could be interpreted entirely differently by those subordinates acquainted with Paul's theology. As mentioned above, Paul parodies the rhetoric of the empire so that his letter may become a double-voiced discourse with special reference to the worship of emperors as part of the imperial propaganda. Through mimicry or parody, Paul as a subordinate in his hidden transcript both seemingly stabilises and eventually destabilises the public transcript of the elites.

Following this line of reasoning, I will first begin with the Greek term $\tau \mu \eta$ [honour] in conjunction with the imperial cult (Romans 13:7). It is quite ambiguous to whom $\tau 1 \mu \eta$ is due. As for the elites, $\tau$ ни would recall the divine honours of Roman emperors in the Greco-Roman honour-shame system (Jewett 2006:803). ${ }^{6}$ By means of parody, Paul ostensibly

\footnotetext{
$6.0 n$ the honour or shame system in the Mediterranean world, confer Malina (1981:31). Pivotal to understanding Romans is the system of honour in the Mediterranean world. Bruce Malina defines honour in the ancient world in what follows: 'Honour' is the value of a person in his or her own eyes (that is, one's claim to worth) plus that person's value in the eyes of his or her social group. Honour is a claim to worth along with the social acknowledgment of worth'. In this respect, the Mediterranean world can be called 'an honour society.' There, honour is granted by the group because the culture in such a society is group-oriented. Honour reveals the worth of a person to others. Romans, of course, was written on the reveas the wediterran basis of the Mediterranean value system, honour and shame. It can be evidenced by enumerating terms regarding honour and shame in Romans: $\tau$ tuń $(2: 7,10 ; 9: 21$

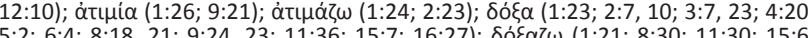
$5: 2 ; 6: 4 ; 8: 18,21 ; 9: 24,23 ; 11: 36 ; 15: 7 ; 16: 27) ; \delta$ ó $\alpha\} \omega(1: 21 ; 8: 30 ; 11: 30 ; 15: 6$

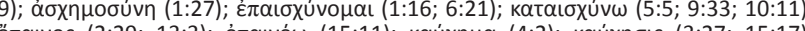

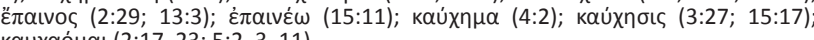
кauxaómal $(2: 17,23 ; 5: 2,3,11)$.
} 
adopts the public transcript of the elites concerning the imperial cult in his discourse. Nonetheless, it would be hasty to conclude that Paul himself claims that 'due honour should be paid to the emperor' like Peter: 'Honour the emperor' ( $\tau$ òv $\beta \alpha \sigma \lambda \lambda \varepsilon \dot{\alpha} \tau \mu \mu \tilde{\alpha} \tau \varepsilon)$ (1 Peter 2:17) (Cuss 1974:42). The reason is that $\tau \iota \mu$ paradoxically can come up with a diametrically opposite case: for the Roman congregations, it is only God who merits such an honour. Jones (1980) tersely notes:

From the perspective of early Christianity, the worst abuse in the Roman Empire was the imperial cult. Honours which should be reserved for God alone could not be bestowed upon men. (p. 1023)

It is thus significant to remember that Paul has already revealed his hidden transcript in Romans 1:18-32 with respect to the imperial cult.

As mentioned above (3.2.), Paul's hidden transcript opposes the divine honours of Roman emperors. It comes as no surprise that the imperial cult as a type of idolatry is a scandal for Paul since he approves no idolatry whatsoever. Furthermore, Paul clearly proclaims that the honour of God is never exchangeable with the honour of a mortal human being (Romans 1:23). The implication is that Paul denunciates the imperial cult granting divine honours to Roman emperors. Most importantly, Paul's general polemic against idolatry conceals his particular accusations on emperor worship in his hidden transcript with a view to avoiding the surveillance by the ruling elites.

Paul's apocalyptic theology enables us to interpret his double-voiced discourse regarding the imperial cult as a form of idolatry. As N. Elliott (2008:146) puts it, apocalyptic rhetoric has a 'strategy of containment' of permitting both individual and community to perceive present situation not as determining the future but as deriving from God's ultimate disposition of human affairs. The assumption is that God will put an end to idolatry in the last judgement in such a way as to punish all those who uphold and enforce it through his wrath (Patte 1983:281). Through such a revelation, an apocalyptic perspective would empower the Roman congregations to break down their contemporary idolatrous system, that is, the imperial cult.

At a glance, Paul's double-voiced discourse seems to simply indicate the coexistence between the elites' public transcript in favour of the imperial cult and his hidden transcript in opposition to it. Yet, it is more correct to claim that the latter both negotiates with and resists against the former. Furthermore, an apocalyptic perspective makes it clear that the imperial cult as a form of idolatry will fall into ruin through God's intervention. If this is the case, public and hidden transcripts are turned upside down because what is adopted in the public transcript proves wrong by means of the revelation of God in Jesus Christ (8:32). As a corollary, this demonstrates that Paul's doubled-voiced discourse eventually turns out to be subversive against the dominant culture.
In the second place, the Greek term $\varphi$ ó $\beta$ o [ [fear] also contains its double-voicedness; it could denote both the fear of civic authority and the fear of God. In the public transcript of the elites, $\varphi$ ó $\beta$ os refers to the fear of 'God-appointed authority' (Käsemann 1973:768). ${ }^{7}$ Paul apparently adopts the public transcript of the elites by stating that the Roman officials may cause fear by punishing the subjects for bad conduct (13:4). He seems to acknowledge that the fear of the rulers is pertinent specifically to such bad conduct as not paying taxes. Therefore, Paul encourages the ruled to pay taxes, indirect and direct (13:6-7).

Nevertheless, fear is ultimately concerned with God rather than the rulers in Paul's hidden transcript. Cranfield (19591960:247-249) connects Romans 13:7 to 1 Peter 2:17. 1 Peter 2:17 distinguishes between the debt owed to God as well as the debt owed to the Roman emperor by proclaiming: 'Fear God. Honour the King' ( $\tau \mu \tilde{\alpha} \tau \varepsilon)$. 1 Peter 2:17 is a single-voiced discourse in the sense that it makes sure to whom fear and honour should be paid respectively. In contrast, Romans 13:7 is a double-voiced discourse because it is ambiguous to whom fear and honour are due. Drawing on the single-voicedness of 1 Peter 2:17, Cranfield (1959-1960:247-249) asserts that, in Romans 13:7, too, $\varphi$ óßo $\varsigma$ was considered as due to God, whilst $\tau \iota \mu$ to the emperor. Taking into account the double-voicedness of Romans 13:7, I, however, instead argue that, whereas póßo and $\tau \mu \eta \dot{~ a r e ~ d u e ~ t o ~ t h e ~ e m p e r o r ~ i n ~ t h e ~ p u b l i c ~ t r a n s c r i p t, ~}$ they are due to God in the hidden transcript. It is important to emphasise that póßos ultimately applies exclusively to God in Paul's hidden transcript. The Hebrew Bible also demonstrates that God is the main object of fear (Genesis 22:12; Psalms 25:14; 33:18; 34:7, 9; 103:11, 13, 17; Proverbs 3:7; 24:21) (Balz 1985:189-219). From this it follows that Paul implicitly signals ultimate fear to be due to God rather than the emperor in his hidden transcript, whilst negotiating with the public transcript of the elites to emphasise their fearful power exercised over the bad conduct of not paying taxes.

Finally, Paul in his hidden transcript eventually highlights the authority ( $\dot{\varepsilon} \xi o v \sigma i ́ \alpha)$ of God rather than that of the rulers. Paul ostensibly acknowledges the authority of the Roman officials through the injunction to submit to governing authorities (Romans 13:1). Importantly, Käsemann (1969:207), however, remarks that the Greek verb $v \pi \circ \tau \alpha \sigma \sigma \varepsilon \sigma \theta \alpha$ means to submit oneself in comparison

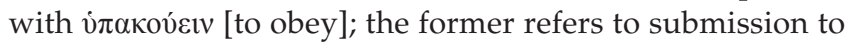
earthly rulers, whilst the latter obedience to God. Likewise, Cranfield (1959-1960:243) notes that the use of vं in the New Testament presumes that 'one is placed below the other person by God and that the other person is superior $\left(\dot{v} \pi \varepsilon \rho \varepsilon \chi^{\prime} \omega v\right)$ to oneself'. In this way, Cranfield regards submission to civil power as an instrument of

7.Ernst Käsemann (1969) translates pó that fear fits in with Romans 13:3 in that fea fits in with Rom term $\varphi \circ \beta \circ \zeta$ objectifies between God and authority, there lurks another question of how to translate it between 'fear' and 'respect. Some English translations like NKJ, NAS, and NAU renders it as 'fear.' Others like NIV, (N)RSV, and NAB translates it as 'respect.' 
God. Remember also that Paul in his hidden transcript puts a strong emphasis on the fact that it is only God - as the ultimate source of sovereignty - who institutes those authorities by stating: 'for there is no authority except from God, and those authorities that exist have been instituted

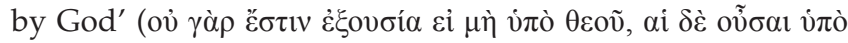

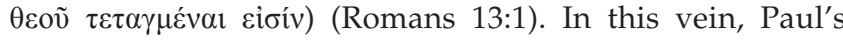
statement that 'anyone who resists authority resists what

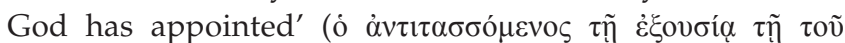
$\theta \varepsilon \circ \tilde{v} \delta 1 \alpha \tau \alpha \gamma \tilde{n} \dot{\alpha} v \theta \dot{\varepsilon} \sigma \tau \eta \kappa \varepsilon v)$ seems to underscore a ban on resistance to the authority of the officials. Yet, a careful look at the perfect tense of the Greek verb $\alpha \dot{\alpha} \theta \dot{\varepsilon} \sigma \tau \eta \kappa \varepsilon v$ ('to resist') tellingly indicates that Paul basically emphasises 'a prior act of opposing the ordinance ordered by God' rather than 'opposing resistance to any authority' (Wan 2008:178). Thus, the underlying implication of Paul's hidden transcript is that the authority of the Roman officials ultimately derives from the unconditional authority of God.

In summary, we have undertaken to do a double-voiced reading of Romans 13:1-7 in a critical conversation with the public or hidden transcripts. The same passage can be read quite differently, depending on whether it is a public voice or a hidden voice. Paul as a subordinate parodies the public transcript of the elites in his hidden transcript in order to avoid their censorship. The end result is that, through parody, Paul creates a space for both negotiation with and resistance against the dominant culture. However, Paul's doubled-voiced discourse ultimately proves subversive against the dominant culture in such a way as to imply that ultimate honour, fear, and authority should go over to God rather than the rulers of the Roman Empire.

\section{Conclusion}

This essay has so far demonstrated the subversiveness of the double-voicedness of Romans 13:1-7, paying special attention to the imperial cult. My argument is that Paul as a colonised subject parodies the public transcript of the elites in his own hidden transcript. This is to say that Paul simultaneously resembles and menaces the dominant discourse. It is through parody that the hidden transcript of the subordinates both co-exists and clashes with the public transcript of the elites. By and large, Paul's theology focused on God in terms of ultimate honour, fear and authority reveals that his hidden transcript eventually undermines the public transcript centred on the veneration of the rulers, in particular the Roman emperors.

The time has come for us to liberate Paul from the suspicion of his being a colonial theologian. From a new perspective on Paul, he never supports an old imperial value of domination and obedience. Rather, he attempts to subvert it, creating a new anti-imperial value of Christianity. We may find the discourse of Romans 13:1-7 to be ambiguous, which swings back and forth between public and hidden voices. But remember that Paul is still whispering in our ears: ultimate honour, fear and authority ultimately lean toward God rather than the imperial rulers.

\section{Acknowledgements}

This essay is the revised version of a paper presented at the SBL Paul and Politics section in New Orleans, November 2009. I would like to express my sincere gratitude to Neil Elliott and Abraham Smith for their constructive criticisms and insightful comments. For sustained conversation about Paul and critical theory, I am particularly thankful to David Balch, Daniel Patte, Larry Welborn, and Sze-kar Wan.

\section{Competing interests}

The author declares that he has no financial or personal relationship(s) that may have inappropriately influenced him in writing this article.

\section{References}

Appian, Bella Civilia, 1913, trans. H. White, Loeb Classical Library, 4 vols., Harvard University Press, Cambridge/London.

Ashcroft, B., Griffiths, G., \& Tiffin, H., 2000, Post-colonial studies: The key concepts, Routledge, London \& New York.

Bakhtin, M., 1984, Problems of Dostoevsky's poetics, transl. Caryl Emerson University of Minnesota Press, Minneapolis.

Balz, H., 1985, ' $\varphi$ ß́ß̧', in G. Kittel \& G. Friedrich (eds.), TDNT 9, transl. G.W. Bromiley, pp. 189-219, W.B. Eerdmans, Grand Rapids.

Bhabha, H., 1994, The location of culture, Routledge, London \& New York.

Bilde, P., 1978, 'The Roman Emperor Gaius (Caligula)'s attempt to erect his statue in the temple of Jerusalem', Studia Theologica 32, 67-93. http://dx.doi. org/10.1080/00393387808599975

Canick, H., 1998 'The end of the world, of history, and of the individual in Greek and Roman antiquit', in J.J. Collins (ed.), The encyclopedia of apocalypticism, Volume 1 : The origins of apocalypticism in Judaism and Christianity, pp. 84-125, Continuum, The origins
New York.

Cassius Dio, Hisroriae Romanae, 1914-1927, transl. E. Carey, Loeb Classical Library, 9 vols., Harvard University Press, Cambridge/London

Cicero, Philippics, 2009, transl. S. Bailey, Loeb Classical Library, 2 vols., Harvard University Press, Cambridge/London.

Cranfield, C.E.B., 1959-1960, 'Some observations on Romans 13: 1-7', New Testament Studies, 241-249.

Cuss, D., 1974, Imperial cult and honorary terms in the New Testament, University Press, Fribourg.

Du Bois, W.E.B., 1969, The souls of black folk, New American Library, New York.

Elliott, N., 2008, The arrogance of nations: Reading Romans in the shadow of empire, Fortress Press, Minneapolis.

Fears, J.R., 1988, 'Ruler Worship', in M. Grant \& R. Kinzinger (eds.), Civilization of the ancient Mediterranean Greece and Rome 2, pp. 1009-1025, Scribner's, New York.

Fitzmyer, J.A., 1993, Romans: A new translation with introduction and commentary, Yale University Press, New York.

Gaventa, B.R., 2005, 'God handed them over: Reading Romans 1:18-32 apocalyptically', Australian Biblical Review 53, 42-53.

Gradel, I., 2002, Emperor worship and Roman religion, Oxford University Press, Oxford

Grant, F.C. (ed.), 1957, Ancient Roman Religion, Liberal Arts Press, New York.

Herbert, J., 1967, Shinto: At the fountain-ead of Japan, Stein and Day, New York.

Holoquist, M., 2002, Dialogism: Bakhtin and his world, Routledge, London and New York.

Horace, 'Epistles', 1926, in Horace, Satires, Epistles, and Ars Poetica, transl. H. R. Fairclough, Loeb Classical Library, Harvard University Press, Cambridge/London.

Horsley, R.A. (ed.), 1997, Paul and Empire: Religion and power in Roman imperia society, Trinity Press International, Harrisburg.

Hunt, A.S. \& Edgar, G.C. (eds.), 1934, Select Papyri II, Harvard University Press, Cambridge.

Jewett, R., 2006, Romans: A commentary, Fortress Press, Minneapolis.

Jones, D.L., 1980, 'Christianity and the Roman imperial cult', Aufstieg und Niedergang der römischen Welt II 23(2), 1023-1054.

Käsemann, E., 1969, 'Principles of the interpretation of Romans 13', in E. Käsemann (ed.), New Testament Question of Today, pp. 196-216, Fortress Press, Philadelphia.

Käsemann, E., 1973, Commentary on Romans, transl. and ed. G.W. Bromiley, Eerdmans, Grand Rapids.

Koortbojian, M., 2013, The divinization of Caesar and Augustus: Precedents, consequences, implications, Cambridge University Press, New York. 
Lendon, J.E., 1997, Empire of honour: The art of government in the Roman world, Oxford University Press, New York.

Lim, S.U., 2011, 'The myth of origin in context through the lens of deconstruction, dialogism, and hybridity', Journal for the Study of Religions and Ideologies 29, $112-131$.

Malina, B.J., 1981, The New Testament world: Insights from cultural anthropology John Knox Press, Atlanta.

Marshall, J.W., 2008, 'Hybridity and reading 13', Journal of the Study for the New Testament 31, 157-178. http://dx.doi.org/10.1177/0142064X08098279

McDonald, J.I.H., 1989, 'Romans 13:1-7: A test case for New Testament interpretation', New Testament Studies 35, 540-49. http://dx.doi.org/10.1017/ S0028688500015204

McLaren, J.S., 2005, 'Jews and the imperial cult: From Augustus to Domitian' Journal of the Study for the New Testament 32, 257-278. http://dx.doi. org/10.1177/0142064X05052506

Patte, D., 1983, Paul's faith and the power of the Gospel: A structural introduction to the Pauline letters, Fortress Press, Philadelphia.

Philo, De Legatione ad Gaium, 1962, transl., F.H. Colson, Loeb Classical Library, Harvard University Press, Cambridge/London.

Pliny the Elder, Naturalis Historia 1969-1986, transl. H. Rackham, Loeb Classica Library, 10 vols., Harvard University Press, Cambridge/London.

Price, S.R.F., 1998, Rituals and power: The Roman imperial cult in Asia Minor Cambridge University Press, Cambridge.
Scott, J.C., 1990, Domination and the arts of resistance: Hidden transcripts, Yale University Press, New Haven.

Seutonius, 'Julius', 1914, in Seutonius, The lives of the Caesars, vol. 1, transl. J.C. Rolfe, Loeb Classical Library, Harvard University Press, Cambridge/London.

Seutonius, 'Nero', 1914, in Seutonius, The lives of the Caesars, vol. 2, transl. J.C. Rolfe, Loeb Classical Library, Harvard University Press, Cambridge/London.

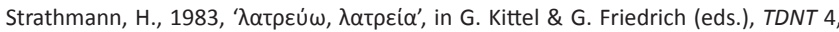
transl. G.W. Bromiley, pp. 58-65, W.B. Eerdmans, Grand Rapids.

Stubbs, M.A., 2004, 'Subjection, reflection, resistance: An African-American reading of the three-dimensional process of empowerment in Romans 13 and the freemarket economy', in I. Khiok-Khang (ed.), Navigating Romans through cultures: Challenging readings by charting a new course, pp. 171-197, T \& T Clark, Challenging
New York.

Tacitus, Annals, 1931, transl. J. Jackson, Loeb Classical Library, 3 vols., Harvard University Press, Cambridge/London.

Virgil, Aeneid, 1935, transl. H.R. Fairclough, Loeb Classical Library, 2 vols., Harvard University Press, Cambridge/London.

Virgil, 'Fourth Eclogues', in 'Virgil, Eclogues, Georgics', Aeneid 1-6, 1916, transl. H.R. Fairclough, Loeb Classical Library, Harvard University Press, Cambridge/London.

Wan, Sze-kar, 2008, 'Coded resistance: A proposed reading of Romans 13:1-7', in C.B. Kittredge, E.B. Aitken \& J.A. Draper (eds.), The Bible in the public square: Reading the signs of the times, pp. 173-184, J.A. Minneapolis, Fortress Press.

Wengst, K., 1997, Pax Romana and the peace of Jesus Christ, SCM, London. 